2011

\title{
Reform of Investor-State Arbitration: A Perspective from Canada
}

Gus Van Harten

Osgoode Hall Law School of York University, gvanharten@osgoode.yorku.ca

Follow this and additional works at: http://digitalcommons.osgoode.yorku.ca/all_papers

\section{Repository Citation}

Van Harten, Gus, "Reform of Investor-State Arbitration: A Perspective from Canada" (2011). All Papers. Paper 31.

http://digitalcommons.osgoode.yorku.ca/all_papers/31

This Working Paper is brought to you for free and open access by the Research Papers, Working Papers, Conference Papers at Osgoode Digital

Commons. It has been accepted for inclusion in All Papers by an authorized administrator of Osgoode Digital Commons. 


\title{
DRAFT of commentary published by the Macdonald Laurier Institute in Ottawa
}

\section{Reform of investor-state arbitration: A perspective from Canada}

\author{
Gus Van Harten, Osgoode Hall Law School, September 2011 gvanharten@osgoode.yorku.ca
}

Canada promotes a rules-based system of international trade and investment. But this leads to further questions. Who interprets the rules and are they institutionally independent and neutral? Does the process function in Canada's interests? In this article, it is argued that Canada should, in trade talks with the US and European Union, seek targeted reform of the current design of investorstate arbitration. A useful model for doing so is Canada's Agreement on Internal Trade. The article's conclusion offers some specific recommendations.

\section{The role of investor-state arbitration}

Investor-state arbitration is a unique form of international adjudication. It allows foreign investors to sue states directly under international law, without resorting first to domestic courts. It is a key forum in which the ambiguities in trade treaties are worked out. The resolution of these ambiguities leads to what one might call arbitrator-made law with important implications for businesses and governments. Investor-state arbitration is also of practical significance because it can lead to the imposition of monetary penalties or affirmative orders against states and large costs awards against investors.

A primary aim of investor-state arbitration is to protect foreign investors from expropriatory, discriminatory, or abusive treatment at the hands of government. More broadly, the system seeks to encourage international investment, although there is mixed evidence on whether investment treaties influence firms in their investment decision-making. ${ }^{1}$

Investor-state arbitration has been invoked in hundreds of cases involving dozens of countries. Most have involved a challenge to a proposed or actual law, regulation, or other government measure. Others have involved disputes about investor-state contracts. They have involved different areas of decision-making, such as tax rules, environmental laws, privatizations "gone wrong," and direct expropriations in the resource sector. Aspects of the Canadian experience in investor-state arbitration are summarized below.

\section{Missing institutional safeguards}

As with other forms of adjudication, the promise of investor-state arbitration lies in its claim to fairness based on principles of impartiality and neutrality. Any system of adjudication that decides important questions of law serves this objective only if it ensures a strong measure of institutional independence. In this respect, there are important weaknesses in investor-state arbitration.

The first is that the arbitrators lack security of tenure. In other international courts and tribunals, such as the Appellate Body of the World Trade Organization, members are appointed for set terms.

\footnotetext{
${ }^{1}$ Yackee, Jason W. (2010). Do Bilateral Investment Treaties Promote Foreign Direct Investment? Some Hints from Alternative Evidence (March 22, 2010). University of Wisconsin Legal Studies Research Paper No. 1114. Available at SSRN: http://ssrn.com/abstract=1594887, as of July 4, 2011. See generally: Sauvant, K.P., and L.E. Sachs (eds.) (2009). The Effect of Treaties on Foreign Direct Investment: Bilateral Investment Treaties, Double Taxation Treaties, and Investment Flows. Oxford: Oxford University Press.
} 


\section{DRAFT of commentary published by the Macdonald Laurier Institute in Ottawa}

At the domestic level, judges are typically appointed for life or until a set retirement age. Secure tenure is widely acknowledged as a core attribute of an independent judiciary in democratic, freemarket societies, based on the institutional separation of powers and the rule of law. Without it, as Lord Denning said, "The judicial power is simply a part of the executive machine."2

The second weakness in investor-state arbitration is the absence of a pre-established roster of persons from which arbitrators must be appointed. Short of judicial security of tenure, a roster is vital to allow quality control, public accountability, and neutrality among the arbitrators. For example, in the case of NAFTA, the treaty's state-state arbitration process (but not its investor-state arbitration process) provides for a roster. Canada, Mexico, and the US each appoint one-third of the roster members prior to any specific dispute. Thus, each state has role in selecting in advance the arbitrators who are eligible to decide future disputes. In the case of investor-state arbitration, the NAFTA text refers to a roster ${ }^{3}$ but none was ever implemented by the NAFTA states.

A third weakness is that the presiding arbitrators of tribunals are not appointed to specific cases through an objective and neutral method. Rather, in the absence of agreement between the disputing parties, the presiding arbitrator is selected by officials at organizations such as the International Centre for the Settlement of Investment Disputes (ICSID) in Washington or the Secretariat of the Permanent Court of Arbitration in The Hague. These officials are certainly not nefarious people, but, harkening back to Lord Denning, it is a serious problem for adjudicator independence that any executive official has the power to appoint an arbitrator with prior knowledge of the specific case. In contrast, in NAFTA state-state arbitration, where the disputing parties cannot agree on whom to appoint, the panel chair is selected at random from the roster. ${ }^{4}$

A fourth weakness of investor-state arbitration is that the arbitrators are not rigorously regulated in the remunerative activities that they may pursue beyond their judicial role. For the most part, those selected as arbitrators in investor-state arbitration are not judges (or former judges) who are appointed on a one-off basis in light of their eminence and detachment from the nitty-gritty of investment law. On the contrary, they are often repeat players in a small "club" of commercial arbitrators, based primarily at private bodies like the International Chamber of Commerce in Paris or the London Court of International Arbitration. ${ }^{5}$ Some law firms have both investor-state arbitrators and investor-state counsel on staff. Even if they are not working on the same case, impartiality problems can arise, such as in the common situation where the resolution of a legal issue in one case is relevant to other cases.

A useful comparison is provided by FINRA (the Financial Industry Regulatory Authority) arbitration in the US, which is used to resolve disputes between securities firms and their customers. ${ }^{6}$ In FINRA arbitration, due to concerns about apparent conflicts of interest, "public" (i.e., securities industry-independent) arbitrators are precluded from working more than $20 \%$ of their time in the securities industry and from being in a firm that earns more than $10 \%$ of its revenue

\footnotetext{
${ }^{2}$ Denning, Lord (1950). The Independence of the Judges. Address to the Holdsworth Club of the University of Birmingham (June 16, 1950), p. 1.

${ }^{3}$ North American Free Trade Agreement, Article 1124.

${ }^{4}$ Ibid, Article 2011.

${ }^{5}$ The seminal study is Dezalay, Y., and B. Garth (1996), Dealing in Virtue: International Commercial Arbitration and the Construction of a Transnational Legal Order.

${ }^{6}$ FINRA Code of Arbitration, sections 12100(p) and (u). Available at http://finra.complinet.com/en/display/display_main.html?rbid=2403\&element_id=4096, as of July 4, 2011.
} 


\section{DRAFT of commentary published by the Macdonald Laurier Institute in Ottawa}

from that industry. FINRA arbitration also provides for the random assignment of arbitrators to specific cases and case lists.

This outline of institutional weaknesses in investor-state arbitration is not meant as a criticism of those who sit as investor-state arbitrators. One should not ask that good people refuse to serve; in the end, their willingness to do so may be all that can salvage a tainted system. The point is rather that the current model does not support the necessary appearance of independence and impartiality in investor-state arbitration and does not provide an adequate foundation for a rules-based system of international trade and investment.

\section{Investor-state cases brought against Canada}

How has Canada, a country that is both a significant capital-importer and capital-exporter, fared so far in the process? The experience has been dominated by investor-state arbitration under NAFTA Chapter 11. Unlike virtually all other investment treaties, Chapter 11 applies to relations between two developed countries and has generated a substantial number of claims against both the US and Canada (typically initiated by the other's investors). The record is summarized below. ${ }^{7}$

NAFTA Chapter 11 claims, by respondent state and claimant nationality (to September 2011)

\begin{tabular}{|l|l|l|l|l|}
\hline $\begin{array}{l}\text { Claimant's } \\
\text { nationality: }\end{array}$ & $\begin{array}{l}\text { Claims against } \\
\text { Canada }\end{array}$ & $\begin{array}{l}\text { Claims against } \\
\text { Mexico }\end{array}$ & $\begin{array}{l}\text { Claims against } \\
\text { the US }\end{array}$ & Totals: \\
\hline Canadian & NA & 1 & 15 & 16 \\
\hline Mexican & 1 & NA & 1 & 2 \\
\hline American & 29 & 15 & NA & 44 \\
\hline Unknown & 0 & 1 & 0 & 1 \\
\hline Totals: & 30 & 17 & 16 & Total claims: 63 \\
\hline
\end{tabular}

NAFTA Chapter 11 claims progressing beyond the filing of notice of a claim, by respondent state and claimant nationality (to September 2011)

\begin{tabular}{|l|l|l|l|l|}
\hline $\begin{array}{l}\text { Claimant's } \\
\text { nationality: }\end{array}$ & $\begin{array}{l}\text { Claims against } \\
\text { Canada }\end{array}$ & $\begin{array}{l}\text { Claims against } \\
\text { Mexico }\end{array}$ & $\begin{array}{l}\text { Claims against } \\
\text { the US }\end{array}$ & Totals: \\
\hline Canadian & NA & 1 & 11 & 12 \\
\hline Mexican & 0 & NA & 0 & 0 \\
\hline American & 19 & 11 & NA & 30 \\
\hline Unknown & 0 & 0 & 0 & 0 \\
\hline Totals: & 19 & 12 & 11 & Total claims: 42 \\
\hline
\end{tabular}

Thus, the federal government has faced 29 claims by US investors, although roughly one-third of these claims appear not to have materialized. Perhaps surprisingly, Canada has been the most frequently-sued NAFTA country.

\footnotetext{
${ }^{7}$ The author collected this data as part of an empirical project on investment treaty arbitration, drawing on academic or government websites that provide awards and other materials in NAFTA investor-state arbitrations. Kirsten Mikadze's research assistance is gratefully acknowledged.
} 


\section{DRAFT of commentary published by the Macdonald Laurier Institute in Ottawa}

There are nine NAFTA cases against Canada that have led to a final win-loss outcome. In these cases, Canada has a mixed record. Three early cases were lost, one based on a fairly capitulatory settlement, ${ }^{8}$ and the others led to a modest award against Canada. ${ }^{9}$

More recently, Canada settled two NAFTA claims by American investors. In Abitibi Bowater, Canada paid about US $\$ 130$ million for the expropriation of properties and water/ timber rights in Newfoundland and Labrador. In Dow AgroSciences, the claim was settled based on Quebec agreeing to a statement that the pesticide 2,4-D does not pose an unacceptable risk to human health or the environment, if used according to instructions. ${ }^{10}$

Canada has also had important "wins" in defending NAFTA cases. These have included successful defences against challenges to the national system of postal delivery, pesticide regulation, lumber export management, and income trusts. In each of these cases, the claim was rejected without a monetary award against Canada. ${ }^{11}$

Finally, there are numerous ongoing cases against Canada, although many are inactive. The active cases involve disputes over, for example, research and development expenditures in the offshore oil sector in Newfoundland and Labrador, implementation of the Green Energy Act in Ontario, a federalprovincial environmental assessment that blocked a proposed quarry in Nova Scotia, and two cases involving hunting and fishing licences in the Northwest Territories and Quebec.

Canada's experience in defending NAFTA claims, on win-loss outcomes, is thus mixed. As well, Canada has not faced claims under the various other investment treaties that it has concluded with developing countries. However, if an investor-state mechanism is adopted in the proposed CanadaEU trade agreement, Canada would likely assume a higher risk of claims under that agreement as well as under NAFTA. ${ }^{12}$

\section{Investor-state cases brought by Canadian investors}

In contrast to Canada's experience defending claims, Canadian investors have an exceedingly poor record in investor-state arbitration. As claimants under NAFTA, they have sued the US government nine times and lost every case (not including ongoing cases, of which only a few appear to be active). ${ }^{13}$ In some NAFTA cases, such as Methanex and Glamis Gold, Canadian investors not only lost

\footnotetext{
${ }^{8}$ Ethyl $v$ Canada, in which Canada is understood to have settled a challenge to restrictions on a gasoline additive by paying about \$16 million in compensation to the investor, issuing a statement that the gasoline additive did not pose a health or environmental threat, and withdrawing the restrictions.

${ }^{9}$ SD Myers v Canada (award against Canada of about US \$6 million plus interest and costs); Pope \& Talbot v Canada (award against Canada of about US $\$ 500,000$ plus interest and costs).

${ }^{10}$ However, Quebec was able to maintain its legislative ban on the use of 2,4-D and other pesticides as a risk-avoidance measure. Other than the statement itself, no compensation was provided in exchange for withdrawal of Dow Chemical's NAFTA claim for US \$2 million for the economic impact of the ban.

${ }^{11}$ UPS v Canada; Chemtura v Canada; Merrill and Ring Forestry v Canada; and Gottlieb v Canada.

12 The potential inclusion of an investor-state mechanism in the Canada-EU trade agreement would expand opportunities for US investor claims against Canada under NAFTA if the Canada-EU agreement omitted NAFTA-style exceptions for existing subnational measures (NAFTA, Article 1108(1)). Faced with a Canada-EU agreement that did not exempt such measures, arbitrators would likely read down the NAFTA exception by referring to the NAFTA principle of most-favoured-nation treatment, thus allowing NAFTA claims to be brought against provincial and municipal measures in Canada, but not state and local measures in the US which would continue to be protected by the exception.

${ }^{13}$ ADF v US; Canfor v US; CCFT v US; Glamis Gold v US; Loewen v US; Methanex v US; Mondev v US; Tembec v US; Terminal $v U S$.
} 


\section{DRAFT of commentary published by the Macdonald Laurier Institute in Ottawa}

the case but were hit with a large costs award in favour of the US government. In some cases, many observers thought that the Canadian investor had a strong claim. The clearest example is Loewen $v$ United States. ${ }^{14}$

In Loewen, a major Canadian funeral home company was driven into bankruptcy after a jury in Mississippi awarded US $\$ 500$ million, including $\$ 75$ million for emotional distress and $\$ 400$ million in punitive damages, against the Canadian investor after a civil trial. The civil lawsuit had involved a contractual dispute over assets worth not more than $\$ 4$ million. Loewen was unable to appeal the award to the Mississippi Supreme Court after the Court declined to waive a requirement that an appellant, as a condition of appeal, file a bond worth $125 \%$ of the damages award at trial.

In the ensuing NAFTA arbitration, the tribunal reviewed the Mississippi trial and characterized it as "a disgrace" "[b]y any standard of measurement." 15 Nevertheless, the tribunal dismissed Loewen's claim on the ground that Loewen should have sought a final appeal at the US Supreme Court, as a substantive requirement of NAFTA's minimum standard of protection (although NAFTA does not contain a duty to exhaust local remedies as a condition of bringing a claim), before initiating a NAFTA claim. At the conclusion of its award, the tribunal made this intriguing statement: ${ }^{16}$

We think it right to add one final word. A reader following our account of the injustices which were suffered by Loewen and Mr. Raymond Loewen in the Courts of Mississippi could well be troubled to find that they emerge from the present long and costly proceedings with no remedy at all. After all, we have held that judicial wrongs may in principle be brought home to the State Party under [NAFTA] Chapter Eleven, and have criticised the Mississippi proceedings in the strongest terms. There was unfairness here towards the foreign investor. Why not use the weapons at hand to put it right? What clearer case than the present could there be for the ideals of NAFTA to be given some teeth?

This human reaction has been present in our minds throughout but we must be on guard against allowing it to control our decision. [....] Too great a readiness to step from outside into the domestic arena, attributing the shape of an international wrong to what is really a local error (however serious), will damage both the integrity of the domestic judicial system and the viability of NAFTA itself. The natural instinct, when someone observes a miscarriage of justice, is to step in and try to put it right, but the interests of the international investing community demand that we must observe the principles which we have been appointed to apply, and stay our hands.

One reading of this statement is that the tribunal thought itself bound to adhere to the customary duty to exhaust local remedies in international law, despite the apparent injustice that this might produce and the evident removal of such a duty in NAFTA. Another reading of the statement, especially its last line, is that the tribunal thought it prudent to downplay Loewen's mistreatment in order to protect the "interests of the international investing community" from a political reaction against NAFTA in the US. If this was a motivation for the tribunal's decision, one wonders what

\footnotetext{
${ }^{14}$ Loewen Group Inc. and Raymond L. Loewen v United States of America, ICSID Case No. ARB(AF)/98/3, Award of 26 June 2003. Available at http://ita.law.uvic.ca/documents/Loewen-Award-2.pdf, as of July 4, 2011.

${ }^{15}$ Ibid, para. 119.

${ }^{16}$ Ibid, para. 241-2.
} 


\section{DRAFT of commentary published by the Macdonald Laurier Institute in Ottawa}

protections NAFTA really offers to Canadian investors who experience mistreatment at the hands of a public authority in the US.

After the Loewen award was issued, the US-appointed member of the tribunal, former US Congressman and appellate judge Abner Mikva, gave a presentation at Pace Law School in which he recounted that, after agreeing to serve on the tribunal, he met with US Department of Justice officials. "You know, judge," he was told by the officials, "if we lose this case we could lose NAFTA." "Well, if you want to put pressure on me," Mikva replied, "then that does it."17

If a former US judge, appointed on a one-off basis, could be approached in this way by a disputing party in a NAFTA investor-state arbitration, then in what ways might powerful actors influence lawyers who stake much of their careers as arbitrators in the field? This larger concern about inappropriate influences in investor-state arbitration was highlighted by a Dutch arbitrator and former banker, Jan Hendrik Dalhuisen, who in August 2010 aired allegations of interference by staff at the International Centre for Settlement of Investment Disputes in the deliberations of an arbitration panel on which he served. ${ }^{18}$ Dalhuisen stated in his reasons for judgment: ${ }^{19}$

"What hovers over all of this is the potentially pernicious impact of the desire for (re)appointment in many [arbitrators], not least for financial gain, in which not only withholding from the parties relevant information... but also incurring the favour of the [CSID] Secretariat, may be important issues in terms of independence...."

Although not evidence of actual bias in any specific case, the winless record of Canadian investors in NAFTA cases against the US gives cause for concern, especially because it draws attention to aspects of the institutional structure that create an apprehension of bias.

Notably, Canadian investors have also lost repeatedly under other investment treaties in all seven known cases that have led to a final outcome. This has included cases against Costa Rica, Croatia, the Czech Republic, Ecuador, Mexico, Sri Lanka, and Venezuela. ${ }^{20}$

Overall, the record of Canadian investors in known arbitrations is 0 wins and 16 losses. This raises the question of whether Canadian interests, and perhaps other countries, are well-served by investorstate arbitration. In particular, in the ongoing Canada-EU trade negotiations, it is an open question why Canada would push to include an investor-state mechanism in a trade agreement between states with mature domestic courts that are available to foreign investors. There are good reasons, at the very least, to reconsider the investor-state model in NAFTA and any Canada-EU agreement in order to ensure that it compares favourably, in its institutional independence, to domestic judicial processes.

\footnotetext{
${ }^{17}$ D. Schneiderman (2010). “Judicial Politics and International Investment Arbitration: Seeking an Explanation for Conflicting Outcomes” Northwestern Journal of International and Business Law 30 (2): 383-416 at 404-5.

${ }^{18}$ Aguas del Aconquija and Vivendi v Argentina, ICSID Case No. ARB/97/3, Annulment Panel Decision of 10 August 2010. Available at http://ita.law.uvic.ca/documents/VivendiSecondAnnulmentDecision.pdf, as of July 4, 2011.

${ }^{19}$ Ibid, para. 25

${ }^{20}$ Anderson v Costa Rica; Ulemek v Croatia; Frontier Petroleum Services v Czech Republic; Encana v Ecuador; International Thunderbird v Mexico; Mihaly v Sri Lanka; Vannessa Ventures v Venezuela.
} 


\section{DRAFT of commentary published by the Macdonald Laurier Institute in Ottawa}

\section{A comparison to the Agreement on Internal Trade}

The person-to-government arbitration process under Canada's Agreement on Internal Trade ${ }^{21}$ was modeled on NAFTA investor-state arbitration in that it allows a business resident in one Canadian jurisdiction to sue the government of another. However, the AIT incorporated a number of important safeguards.

First, person-to-government arbitration under the AIT is based on a roster of arbitrators, appointed by the governments that concluded the agreement. ${ }^{22}$ This allows for quality control and public accountability, while supporting independence and neutrality.

Second, the AIT has a mandatory code of conduct for arbitrators. ${ }^{23}$ Among other things, the code requires arbitrators to "observe high standards of conduct so that the integrity and impartiality of the dispute settlement process is preserved." It includes ongoing disclosure obligations - including in relation to professional relationships of the arbitrator or the arbitrator's employer - with persons who may benefit from the outcome of the proceeding or from any issue that may be decided. In the absence of judicial security of tenure, these are important checks.

Third, the AIT requires that panel chairs have expertise in administrative law. ${ }^{24}$ Speaking as an academic who specializes in administrative law, I would of course support this requirement in all instruments that authorize investor-state arbitration. Jests aside, this area of expertise is useful in investor-state arbitration because, typically, the disputes arise from laws, regulations, or similar measures passed by governments, rather than from commercial acts of another private party. (I should add, perhaps, that I have not worked as a lawyer or arbitrator in investor-state arbitration and have no aspiration to do so.)

Fourth, the AIT has a screening mechanism. ${ }^{25}$ Claims are referred first to an independent officer, often a former trade negotiator, academic, or lawyer, who is appointed by the home province of the person bringing the claim. The screener has the authority to cull claims that are frivolous or vexatious, that are harassing, or that do not show a reasonable case of injury or denial of benefits. I suspect the mechanism may not be popular among any lawyers who may be keen to see litigation under the AIT, but it has the benefit of saving the parties from expensive and arduous arbitrations of claims that are unlikely to succeed.

The AIT setup does not satisfy entirely the standards of independence of a domestic or international court but it delivers a much greater measure of independence than investor-state arbitration. This is primarily because the arbitrators are appointed in an objective manner from a set roster and because there are mandatory checks on activities that may generate conflicts of interest.

\footnotetext{
${ }^{21}$ Agreement on Internal Trade, Consolidated Version 2010, ch. 17, part B. Available at http://www.ait-aci.ca/index_en/ait.htm, as of July 4, 2011.

${ }_{22}^{2}$ Ibid, Article 1715 and Annex 1704.

${ }^{23}$ Ibid, Annex 1719. A binding code of conduct is also needed for persons acting as counsel in investor-state arbitration. See Bishop, Doak (2010). Ethics in International Arbitration. Presentation to the XXth Congress of the International Council on Commercial Arbitration, Rio de Janeiro, May 23-26, 2010. Available at http://www.arbitrationicca.org/media/0/12763302233510/icca_rio_keynote_speech.pdf, as of July 4, 2011.

${ }^{24}$ Ibid, Article 1715(1).

${ }^{25}$ Ibid, Article 1712.
} 


\section{DRAFT of commentary published by the Macdonald Laurier Institute in Ottawa}

\section{Conclusion and recommendation}

In border and trade talks with the US and the European Union, Canada should seek to improve the institutional framework of investor-state arbitration. As it happens, one of the best models appears to be a Canadian one: the Agreement on Internal Trade. Based on this model and its underlying principles, Canada should target these improvements in investor-state arbitration:

- a pre-set roster from which all arbitrators would be appointed;

- an objective method to select tribunal chairs where the parties do not agree;

- rigorous checks on outside remunerative activities by arbitrators;

- a binding code of conduct for arbitrators;

- a duty to resort to reasonably-available local remedies, especially in the case of states with mature domestic court systems; and

- an independent screening process to weed out claims that are frivolous, harassing, or unlikely to succeed.

These adjustments would remove apparent conflicts of interest among investor-state arbitrators. They would support a fair and neutral process of dispute settlement as an integral part of a rulesbased system of trade and investment. And they fit closely with the values and interests of Canada and other trading nations committed to the rule of law. 